\title{
Ecophysiology of cowpea (Vigna unguiculata L.) cultivated under different saline and biofertilizer levels
}

\author{
Rafael Santiago da Costa', Letícia Kenia Bessa de Oliveira', Aiala Vieira Amorim², Fred Denilson \\ Barbosa Silva ${ }^{2}$, Albanise Barbosa Marinho², Sebastião Medeiros Filho', Rosilene Oliveira \\ Mesquita'
}

\author{
${ }^{1}$ Department of Agronomy/Plant Science, Federal University of Ceará, Fortaleza, Ceará, Brazil \\ ${ }^{2}$ Institute of Rural Development, University for the International Integration of Afro-Brazilian Lusophony, \\ Redenção, Ceará, Brazil
}

\section{*Corresponding author: rafaelsantiagodacosta@yahoo.com.br}

\section{Abstract}

The objective of this study was to evaluate the growth, physiology, and production of cowpea plants grown under different levels of salinity and doses of mixed biofertilizer. The experiment was set in a completely randomized $3 \times 4$ factorial design, corresponding to three levels of irrigation with saline water (ECW: 0.5, 2.5 and $\left.4.5 \mathrm{dS} \mathrm{m}^{-1}\right)$ and four doses of biofertilizer $(0,800,1600$ and 2400 milliliters - $\mathrm{mL}$ ), with five repetitions. The biofertilizer was obtained by means of an aerobic process, using a mixture of water, goat manure, and wood ashes, and it was applied in the liquid form, once a week, and directly into the soil. After 70 days, gaseous exchanges were evaluated, and the length of the main stem, the diameter of the stem, and the leaf area were measured. Furthermore, the number of pods produced, mean pod size, total pod weight, total seed weight, hundred seed weight, and yield were estimated. It was observed that the application of mixed biofertilizer promoted increments of $28.98 \%$ in leaf area, $32.78 \%$ in length of the main stem, and $21.55 \%$ in total dry mass. Weekly doses of $1600 \mathrm{~mL}$ promoted significant increases in gas exchanges. The application of weekly doses of $1600 \mathrm{~mL}$ of mixed biofertilizer promoted growth increases in physiological and productive parameters when the plants were irrigated with saline water up to $2.5 \mathrm{dS} \mathrm{m}^{-1}$, suggesting that the biofertilizer reduces the deleterious effects of salinity.

Keywords: Biofertilization; Gas exchange; Organic fertilization; Yield; Salinization.

Abbreviations: ECW_Electrical conductivity of water; $\mathrm{mL}$ _milliliters; DAP_days after planting.

\section{Introduction}

Cowpea (Vigna unguiculata (L.) Walp.) is one of the main annual legumes included in the diet of many people around the world, contributing to food sovereignty (Gbaguidi et al., 2013). It belongs to the family Fabaceae, originated in Africa, and is a rustic species, of easy management, well adapted to the soil and climatic conditions of the Semiarid region of Brazil, and with good economic profitability (Silva et al., 2016).Cowpea production has been historically concentrated in the Northeast and North regions of the country (Dias et al., 2016).

Soil and water salinity represents one of the main problems in agricultural production systems around the world, as they directly affect the physiological and metabolic processes, inhibiting plant growth and production (Ambede et al., 2012; Pereira et al., 2017). Therefore, the responses of cultivated plants in environments with high salt concentrations have become one of the topics that most interest researchers (Mohamed et al., 2015). Notwithstanding the challenges, the effects of salinity have been successfully overcome in several parts of the world through the use of strategies such as use of salt-tolerant species, adequate irrigation management practices, crop rotation, and use of organic inputs such as mixed biofertilizer (Lacerda et al., 2011; Neves et al., 2015). The use of biofertilizers has proved to be a viable alternative because besides promoting physical and chemical improvements of the soil, liquid fertilizers applied to the substrate surface forms a layer that prevents high water loss by evaporation, allowing the plant cells to remain turgid for longer periods of time (Ju et al., 2018). It is also worth mentioning that because biofertilizers have an organic nature, they can add value to the product offered, give an environmentally correct destination to the waste that would be underutilized in the agricultural properties, and therefore enable a more sustainable agricultural production.

Studies have shown that the use of biofertilizers in saline environments can partially attenuate the effects of salinity on growth and productivity, and help to enhance the physiological efficiency of plants. Thus, the quality and management of biofertilizers must be evaluated before use (Souza et al. al., 2016). In this sense, Sousa et al. (2018) analyzed the saline stress in soybean plants using different organic fertilizers and observed that the application of crab biofertilizer attenuated the saline stress, improving 
physiological and growth variables in relation to plants growing without biofertilizer.

Silva et al. (2013) also found that increased salt concentration in irrigation water impaired photosynthesis, stomatal conductance, transpiration, and productivity in cowpea, but with lower intensity in soils where bovine biofertilizer was applied. In this context, the objective of the present work was to evaluate the growth, gas exchange, and productive parameters of cowpea cultivated under different levels of salinity and biofertilizer doses.

\section{Results and Discussion}

\section{Biometric Parameters}

The analysis of the biometric variables of cowpea revealed that the stem diameter did not show a significant response to the factors studied. According to Formiga et al. (2014), this variable is strongly influenced by the amount of water that the plants receive during the cycle. Thus, it is possible that the diameter of the stem was not influenced because the plants were well irrigated, and also by the beneficial action of the mixed biofertilizer to increase of the water retention in the soil.

In the case of leaf area, only the biofertilizer had a significant effect, fitting a second degree equation, reaching the maximum point of $5302.33 \mathrm{~cm}^{2}$ when the cowpea was fertilized with a dose of $1739.7 \mathrm{~mL}$ of mixed biofertilizer per week. When comparing the maximum with the minimum point $\left(3765.94 \mathrm{~cm}^{2}\right)$ obtained when the plants were not fertilized with a mixed biofertilizer, there was an increase of 28.98\% in the plants that received the fertilizer (Fig. 1).

Similar results were found by Silva et al. (2017) with the same species cultivated with a biofertilizer. They observed that cowpea plants had a larger leaf area when they were biofertilized. According to Silva et al. (2011), the application of liquid biofertilizers promotes greater availability of mineral nutrients and physical and chemical improvements in the soil, favoring the production of new leaves by the plants. Therefore, the greater leaf area found when the plants received mixed biofertilizer was a result of the positive effect of the biofertilizer in providing greater amounts of nutrients for the formation of plant organs.

Interactions between salinity and biofertilizer were seen to act on the length of the main stem, fitting two second degree equations related to the responses of the plants submitted to irrigation with 0.5 and $4.5 \mathrm{dS} \mathrm{m}^{-1}$ saline water. In general, cowpea plants that received $0.5 \mathrm{dS} \mathrm{m}^{-1}$ water (low salinity) had a longer stem length than those irrigated with $4.5 \mathrm{dS} \mathrm{m}^{-1}$ water at all biofertilizer doses applied, reaching a maximum of $4.21 \mathrm{~m}^{\text {plant }}{ }^{-1}$ when they were fertilized with a $1500 \mathrm{~mL}$ dose of mixed biofertilizer, presenting an increase of $32.78 \%$ in relation to plants that were grown without biofertilizer (Fig. 2). As for responses of the plants irrigated with $2.5 \mathrm{dS} \mathrm{m}^{-1}$ saline water, a linear reduction of $0.0003 \mathrm{~m}$ plant $^{-1}$ was observed for each increase of dose, suggesting that at this level of salinity the biofertilizer had no positive effect in reducing the deleterious damage caused by salinity (Fig. 2).

Despite the negative effect of salinity on bean growth, especially when the plants were irrigated with saline waters at concentrations of 2.5 and $4.5 \mathrm{dS} \mathrm{m}^{-1}$, the negative effects were less intense when the plants were biofertilized, possibly due to the absorption of organic ions supplied by this fertilizer. Furthermore, Dinesh et al. (2010) explained that the application of the biofertilizer improves soil attributes, favoring a greater availability of nutrients and allowing a greater allocation of carbohydrates to the shoots of plants, reducing the deleterious effects of salts.

Soil and water salinity represents one of the main obstacles for agricultural production systems worldwide. However, its effects can be reduced with the use of some strategies, as for example the use of organic inputs, such as mixed biofertilizers (Mishra et al., 2014; Shrivastava et al., 2015). Thus, increasing responses when the plants were irrigated with 0.5 and $4.5 \mathrm{dS} \mathrm{m}^{-1}$ water up to a given dose of mixed biofertilizer indicate that the fertilizer may have partially attenuated the effect of the salts on the plants. This did not occur, however, in plants irrigated with $2.5 \mathrm{dS} \mathrm{m}^{-1}$ water, causing a reduction in growth.

According to Silva et al. (2013), increased soil salinity due to irrigation with saline water may inhibit the development and accumulation of plant biomass as a consequence of changes in the physiological parameters of the crop. In this sense, interactions between salinity and biofertilizer were observed in the total dry mass of cowpea; different responses were observed for each level of salinity of the water applied to the plants (Fig. 3).

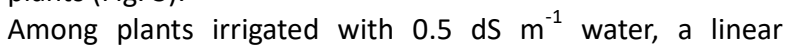
increment of $0.006 \mathrm{~g}$ in the total dry mass plant ${ }^{-1}$ was observed for each increase in the dose of the biofertilizer applied, indicating that the biofertilizer promoted larger increments in grams at this dose. In the case of plants irrigated with $2.5 \mathrm{dS} \mathrm{m}^{-1}$ water, a second degree equation was fitted, reaching a maximum of $73.98 \mathrm{~g}$ of total dry mass when the plants were fertilized with a dose of $1300 \mathrm{~mL}$ of mixed biofertilizer per week (Fig. 3). Nobre et al. (2010) and Bargaz et al. (2018) state that the biofertilizer applied to the soil can induce a greater osmotic adjustment of the plants through the accumulation of organic solutes, promoting the absorption of water and nutrients in saline media, which explains the positive responses even under saline conditions. The positive impacts of microbial biofertilizers on growth, biomass accumulation, and production of basic crops in saline environments are also related to the association of microorganisms belonging to different functional groups that can promote plant growth and improve the productive system and agroecosystem as a whole (Malusá et al., 2012). However, when cowpea plants were irrigated with $4.5 \mathrm{dS} \mathrm{m}^{-1}$ water, it was verified that they presented a linear reduction of $0.0011 \mathrm{~g}$, even despite the provision of mixed biofertilizer (Fig. 3). This indicates that the toxic effect of high salinity conditions is so severe that the plant cannot develop well even being fertilized. According to Aquino et al. (2017), when plants are in severe conditions of salinity, their biomass accumulation drops, even receiving biostimulants, because of the deleterious effects of the salinity. This may be due to the fact that saline ions accumulate in the plant vacuoles to reduce its water potential, closing the stomata and causing excessive accumulation of toxic ions that promote metabolic and morphological disturbances (Acosta-Motos et al., 2017).

\section{Physiological Parameters}

Regarding the physiological responses, only the biofertilizer had a significant effect on stomatal conductance, photosynthesis and transpiration of cowpea plants. In general, the analyzed variables responded in a similar way, because are intrinsically interconnected, presenting positive responses until a certain dose of mixed biofertilizer. Such responses are related to the accumulation of organic ions in the plant, aiding in osmoregulation and increasing the physiological efficiency of the plants (Fig. 4). According to Reis et al. (2016) and Zandonadi et al. (2013), when plants 
are biofertilized, they accumulate higher levels of nutrients in the leaves and this favors the maintenance of physiological functioning and synthesis of osmoregulators. A maximum point of $3.73 \mathrm{~mol} \mathrm{~m}^{-2} \mathrm{~s}^{-1}$ was found for stomatal conductance when the plants were submitted to a weekly dose of $1550 \mathrm{~mL}$ of mixed biofertilizer. From that dose onwards, there was a decrease of stomatal opening, possibly caused by excessive accumulation of ions (Fig. 4A). Following the same pattern, photosynthesis and transpiration presented maximum points of $9.46 \mu \mathrm{mol} \mathrm{m} \mathrm{m}^{2} \mathrm{~s}-1$ and 4.89 $\mathrm{mmol} \mathrm{m} \mathrm{m}^{2} \mathrm{~s}-1$ when fertilized with doses of 1562.5 and $1583.3 \mathrm{~mL}$ of mixed biofertilizer, respectively (Figures $4 \mathrm{~B}$ and $4 C)$. The comparison between the maximum and the minimum (when the plants were not fertilized $-0 \mathrm{~mL}$ ) points of each variable, there were increases of $65.72 \%$ in stomatal conductance, $20.08 \%$ in photosynthesis, and $40.08 \%$ in transpiration (Fig. 4).

According to Taiz et al. (2017), plants open their stomata to capture atmospheric $\mathrm{CO}_{2}$ for photosynthesis, which assists in the accumulation of biomass and production of sugars. Therefore, increased stomatal opening caused by the application of the mixed biofertilizer promoted higher photosynthetic rates in the plants, which may have positively influenced the growth of cowpea.

While the influx of atmospheric $\mathrm{CO}_{2}$ to the leaves takes place, there is a consequent increase in water loss through transpiration (Giuliani et al., 2018). This was evident in the present study. According to Chaves et al. (2011), stomatal cells respond to multiple exogenous and endogenous signals such as light, $\mathrm{CO}_{2}$ concentration, vapor pressure deficit, among others, and this allows plants to quickly adjust their stomatal opening in response to changes in the surrounding environment, so as to optimize the balance between loss of water vapor and absorption of $\mathrm{CO}_{2}$.

In this sense, Silva et al. (2017) studied cowpea plants irrigated with saline water and fertilized with biofertilizer and noted that the biofertilized plants presented a smaller reduction in physiological parameters in relation to the plants that did not receive the fertilizer, demonstrating the ability of the biofertilizer to soften the negative effects of saline water. This may occur due to the action of humic substances present in the biofertilizer, which stimulate the production of organic solutes such as proteins, soluble carbohydrates, and enzymes that provide the osmotic adjustment of the plants under salty conditions (Nardi et al., 2016).

\section{Productive Parameters}

As for the productive variables, it was observed that only the biofertilizer had a significant effect on the average size of pods, presenting a maximum point of $17.03 \mathrm{~cm}$ when cowpea was fertilized with a weekly dose of $1350 \mathrm{~mL}$ of the mixed biofertilizer. When the maximum point was compared to the minimum $(13.49 \mathrm{~cm})$, there was an increase of $20.79 \%$ in average pod size in plants that received the mixed biofertilizer in relation to those that did not (Figure 5).

Pod size is a very important characteristic because the larger the pod, the greater is the number of grains and consequently the greater the yield of the crop (Bezerra et al., 2018). Thus, the application of biofertilizer again proved to be a viable alternative, for it promoted significant increases in pod size. This may have occurred due to the greater availability and distribution of nutrients to formation and development of pods, because cowpea plants present a greater demand for nutrients and water in the reproductive phase. Thus, good availability of nutrients is necessary to reach satisfactory yields.

With respect to the hundred seed weight, there was a significant interaction between salinity and biofertilizer, fitting three linear equations with determination coefficients of 0.99 for the bean irrigated with $0.5 \mathrm{dS}^{-1}$ water, 095 for those irrigated with $2.5 \mathrm{dS} \mathrm{m}^{-1}$ water, and 0.97 for plants receiving $4.5 \mathrm{dS} \mathrm{m}^{-1}$ water, with increasing increments of $0.0089,0.0053$ and $0.0046 \mathrm{~g}$, respectively (Fig. 6A). In general, the biofertilizer promoted increases at all the salinity levels, according to the increase of the doses; however, we observed that plants irrigated with $0.5 \mathrm{dS} \mathrm{m}^{-1}$ water had superior results in all the doses compared to those receiving 2.5 and $4.5 \mathrm{dS} \mathrm{m}^{-1}$ water (Fig. 6A).

Positive results of the increasing biofertilizer doses at all salinity levels for the variable hundred seed weight are directly related to the better nutrition of the plants, which instead of absorbing and accumulating saline ions, assimilated in organic ions into their organs and this promoted better responses. However, water with higher electrical conductivity $\left(2.5\right.$ and $4.5 \mathrm{dS} \mathrm{m}^{-1}$ ) caused higher stress in the plants, leading to a reduction in growth, leaf area and, consequently, in the productive aspects of cowpea plants.

Salinity is one of the abiotic stresses that most limit growth, development, mineral nutrition, and plant productivity worldwide (Shrivastava et al., 2015, Petropoulos et al., 2017), and is one of the main problems in agriculture. The use of salt water to irrigate crops causes excessive accumulation of salts in the soil and ultimately reduces nutrient uptake by the plants, reducing crop yield (Taiz et al., 2017; Lima et al., 2014). This was observed in the present work.

For the variables number of pods per plant, total pod weight, and total seed weight, it was seen that salinity was the only factor causing significant responses. In general, the three variables presented reductions as a function of the increase of water salinity, but plants irrigated with 0.5 and $2.5 \mathrm{dS} \mathrm{m}^{-1}$ water did not present significant differences. On the other hand, when plants were irrigated with $4.5 \mathrm{dS} \mathrm{m}^{-1}$ water, they presented a reduction of $29.30 \%$ in number of pods produced, $27.65 \%$ in total pod weight, and $57.62 \%$ in total seed weight, when compared to plants that were irrigated with water of lower salinity $\left(0.5 \mathrm{dS} \mathrm{m}^{-1}\right)$ (Table 1$)$. This findings confirm the negative effect of salinity on the productive variables.

Similar responses were found by Oliveira et al. (2013) who worked with cowpea plants submitted to irrigation with saline water and biofertilizer. They verified a significant reduction in the number of pods produced and grain weight when the plants were irrigated with $3 \mathrm{dS} \mathrm{m}^{-1}$ saline water, corroborating with the present work. According to AcostaMotos et al. (2017), severe levels of salinity cause osmotic, toxic and nutritional effects, which end up affecting the net assimilation of $\mathrm{CO}_{2}$, inhibiting the leaf expansion, and accelerating the senescence of mature leaves, consequently reducing the area destined to the photosynthetic process and the total production of photoassimilates. Thus, the reductions in the three productive variables evaluated when plants were irrigated with $4.5 \mathrm{dS}^{-1}$ saline water confirmed that cowpea has reduced production when submitted to salt stress.

In relation to yield, a significant response was observed only for biofertilizer doses. No influence of salinity was seen, possibly due to the adaptation of the crop during its life cycle. When the plants received weekly doses of $1428.33 \mathrm{~mL}$ 
Table 1. Mean number of pods per plant (NPP), total pod weight (TPW), and total seed weight (TSW) of cowpea submitted to three levels of salinity (ECW: $0.5,2.5$ and $4.5 \mathrm{dS} \mathrm{m}^{-1}$ ).

\begin{tabular}{cccc}
\hline Variables & \multicolumn{3}{c}{ Levels of salinity } \\
\cline { 2 - 4 } & $0.5 \mathrm{dS} \mathrm{m}^{-1}$ & $2.5 \mathrm{dS} \mathrm{m}^{-1}$ & $4.5 \mathrm{dS} \mathrm{m}^{-1}$ \\
\hline Number of pods & $21.50 \mathrm{a}$ & $19.40 \mathrm{a}$ & $15.20 \mathrm{~b}$ \\
Total pod weight $(\mathrm{g})$ & $54.98 \mathrm{a}$ & $53.39 \mathrm{a}$ & $39.78 \mathrm{~b}$ \\
Total seed weight $(\mathrm{g})$ & $34.5 \mathrm{a}$ & $29.67 \mathrm{a}$ & $14.62 \mathrm{~b}$ \\
\hline
\end{tabular}

Means followed by the same letter do not differ significantly by the Tukey test at $5 \%$ probability.

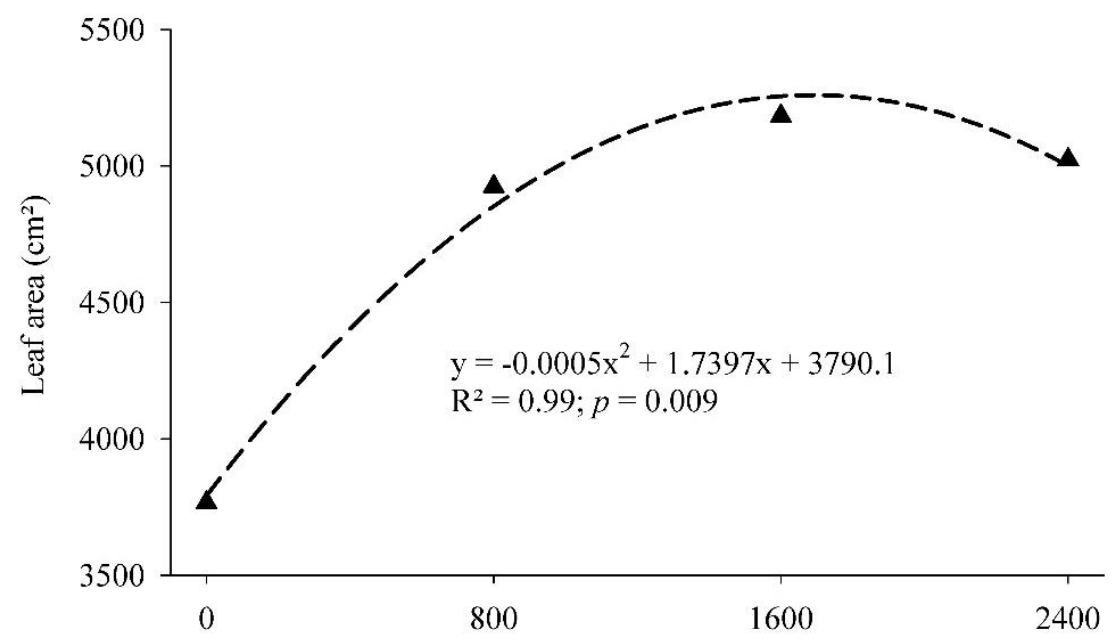

Biofertilizer Doses $(\mathrm{mL})$

Fig 1. Leaf area of cowpea submitted to four doses of mixed biofertilizer $(0,800,1600$ and $2400 \mathrm{~mL}) .{ }^{* *}$ Significant at $1 \%$ probability.

Table 2. Chemical soil attributes in the 0 to $0.20 \mathrm{~m}$ depth layer where cowpea plants were grown.

\begin{tabular}{|c|c|c|c|c|c|c|c|c|c|c|c|c|c|}
\hline C & $\mathrm{N}$ & $\mathrm{OM}$ & $\mathrm{C} / \mathrm{N}$ & $\mathrm{Ca}^{2+}$ & $\mathrm{Mg}^{2+}$ & $\mathrm{Na}^{+}$ & $\mathrm{K}^{+}$ & $\mathrm{H}^{+}+\mathrm{Al}^{3+}$ & $\mathrm{Al}^{3+}$ & $\mathrm{S}$ & $\mathrm{T}$ & $\mathrm{P}$ & $\mathrm{pH}$ \\
\hline \multicolumn{4}{|c|}{$\left(\mathrm{g} \mathrm{kg}^{-1}\right)$} & \multicolumn{8}{|c|}{$\left(\mathrm{cmol}_{\mathrm{c}} \mathrm{kg}^{-1}\right)$} & $\left(\mathrm{mg} \mathrm{kg}^{-1}\right)$ & \\
\hline 11.6 & 1.2 & 20.1 & 10 & 4.2 & 1.9 & 0.21 & 0.26 & 1.65 & 0.15 & 6.6 & 8.2 & 42.33 & 6.6 \\
\hline
\end{tabular}

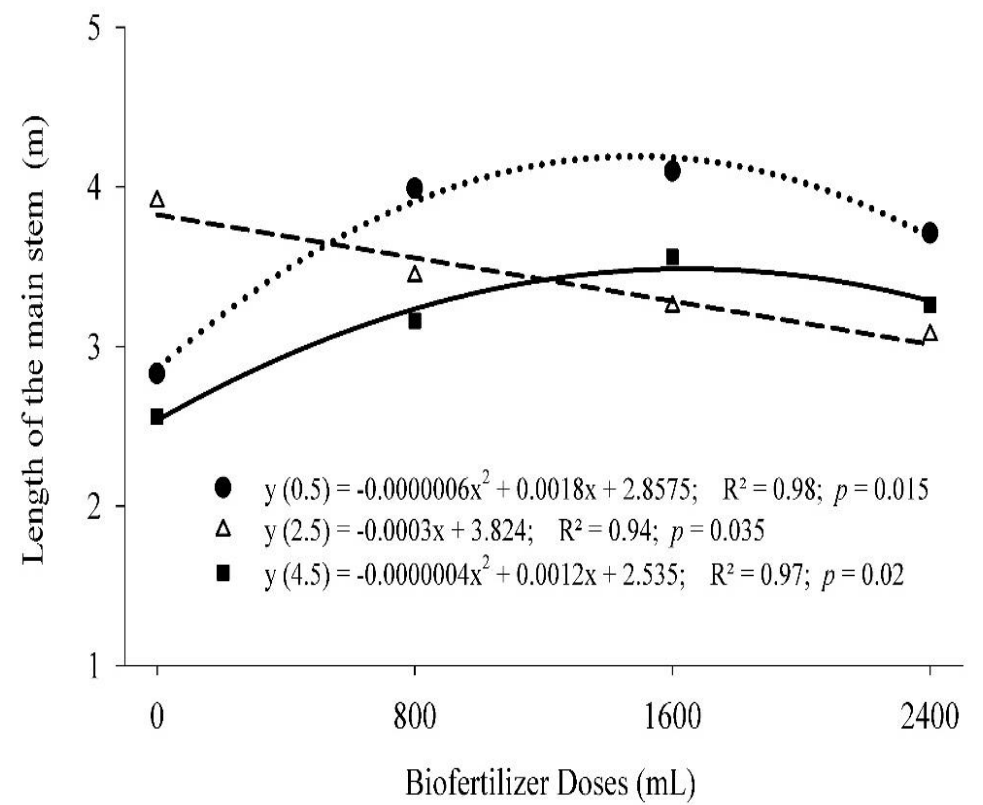

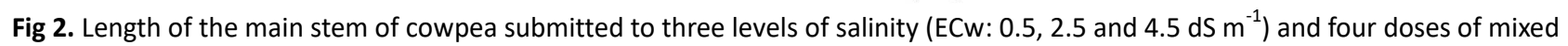
biofertilizer $(0,800,1600$ and $2400 \mathrm{~mL}) .{ }^{* *}$ Significant at $1 \%$ probability 
Table 3. Chemical composition of the biofertilizer applied to the soil for the cultivation of cowpea.

\begin{tabular}{cccccccccccc}
\hline \multirow{2}{*}{ № The application } & \multicolumn{10}{c}{$\left(\mathrm{mg} \mathrm{L}^{-1}\right)$} \\
\cline { 2 - 14 } & $\mathrm{N}$ & $\mathrm{P}$ & $\mathrm{P}_{2} \mathrm{O}_{5}$ & $\mathrm{~K}$ & $\mathrm{~K}_{2} \mathrm{O}$ & $\mathrm{Ca}$ & $\mathrm{Mg}$ & $\mathrm{Fe}$ & $\mathrm{Cu}$ & $\mathrm{Zn}$ & $\mathrm{Mn}$ \\
\hline 1 & 129.2 & 51.38 & 104.75 & 3028.85 & 3695.19 & 255.65 & 719.12 & 4.76 & 0.01 & 4.21 & 5.09 \\
2 & 186.7 & 50.95 & 116.67 & 3038.46 & 3926.92 & 282.47 & 892.69 & 2.05 & 0.01 & 3.47 & 7.47 \\
3 & 108.2 & 54.72 & 86.6 & 2575.76 & 3142.42 & 195.17 & 614.94 & 2.4 & 0.01 & 4.41 & 4.39 \\
4 & 107 & 53.06 & 121.51 & 2783.51 & 3395.88 & 320.25 & 728.3 & 4.54 & 0.01 & 6.67 & 8.28 \\
5 & 130.3 & 50.03 & 104.90 & 3106.64 & 3790.10 & 263.38 & 738.69 & 3.44 & 0.01 & 4.69 & 6.31 \\
\hline
\end{tabular}

Note. Source: Laboratory of Chemistry and Soil Fertility of the Federal University of Ceará.

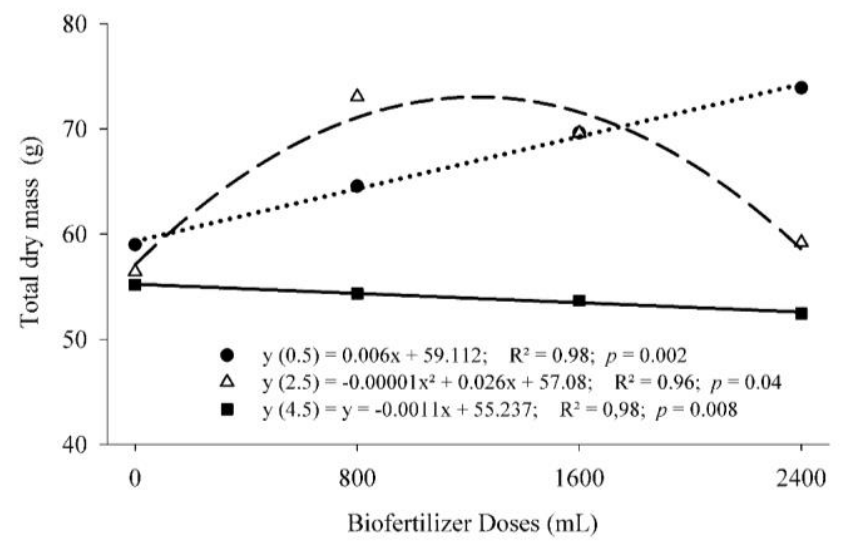

Fig 3. Total dry mass of cowpea submitted to three levels of salinity (ECW: $0.5,2.5$ and $4.5 \mathrm{dS} \mathrm{m}^{-1}$ ) and four doses of mixed biofertilizer $(0,800,1600$ and $2400 \mathrm{~mL})$. **Significant at $1 \%$ probability.

Table 4. Fertilization recommended $\left(\mathrm{kg} \mathrm{ha}^{-1}\right)$ for cowpea culture based on the results of soil chemical analysis.

\begin{tabular}{|c|c|c|c|c|c|c|c|}
\hline \multirow{3}{*}{$\begin{array}{l}\text { Epoch } \\
\text { Planting }\end{array}$} & \multirow{2}{*}{$\begin{array}{l}\mathrm{N} \\
-\end{array}$} & \multicolumn{3}{|c|}{$\begin{array}{c}P \\
P \text { in soil }\left(\mathrm{mg} \mathrm{dm}^{-3}\right)\end{array}$} & \multicolumn{3}{|c|}{$\begin{array}{c}\mathrm{K} \\
\mathrm{K} \text { in soil }\left(\mathrm{mg} \mathrm{dm}^{-3}\right)\end{array}$} \\
\hline & & 0 the 5 & 06 the 10 & $>10$ & 0 the 25 & 26 the 50 & $>50$ \\
\hline & - & 60 & 40 & 20 & 40 & 30 & 20 \\
\hline Coverage & 20 & - & - & - & - & - & - \\
\hline
\end{tabular}

Note. Source: Ribeiro, 2002
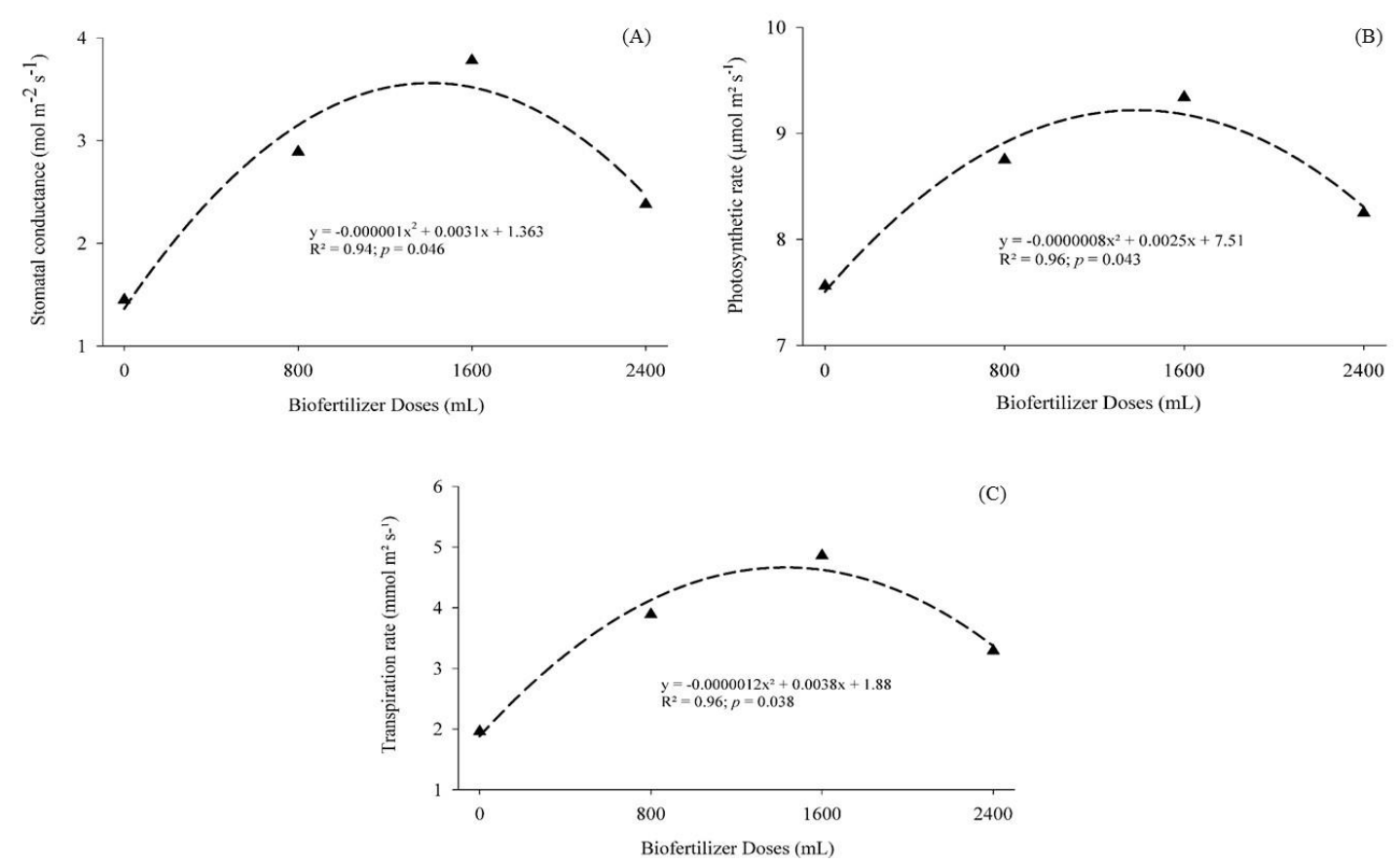

Fig 4. Stomatal conductance (A), photosynthetic rate (B), and transpiration rate (C) of cowpea submitted to four doses of mixed biofertilizer $(0,800,1600$ and $2400 \mathrm{~mL})$. *Significant at $5 \%$ probability. 


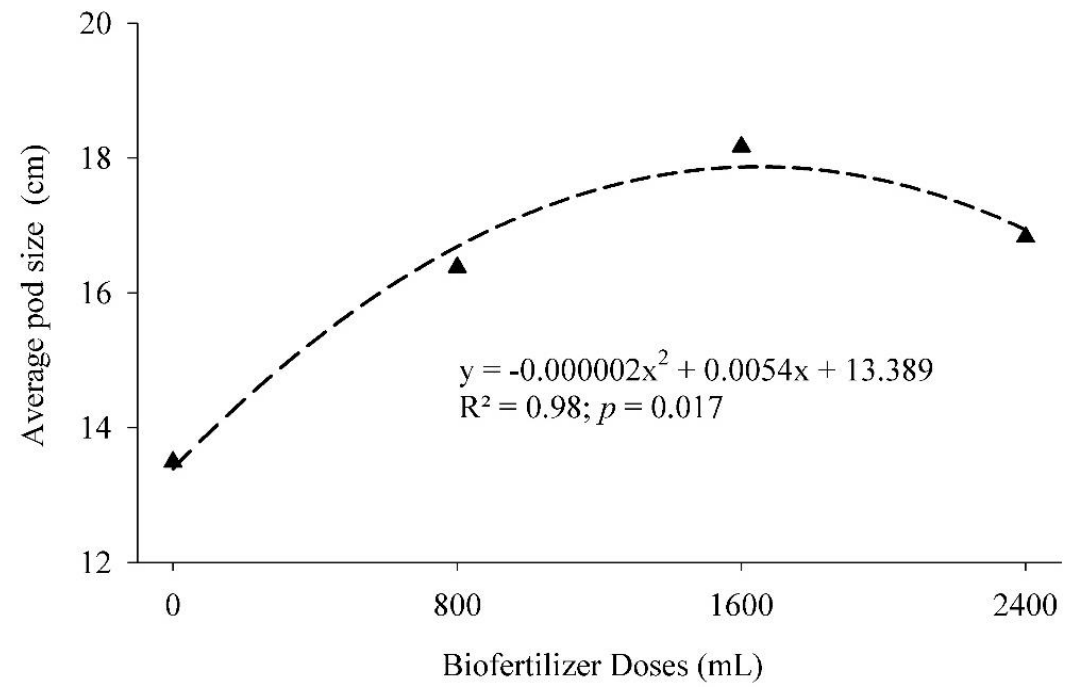

Fig 5. Average cowpea pod size submitted to four doses of mixed biofertilizer (0, 800, 1600 and $2400 \mathrm{~mL})$. *Significant at $5 \%$ probability.
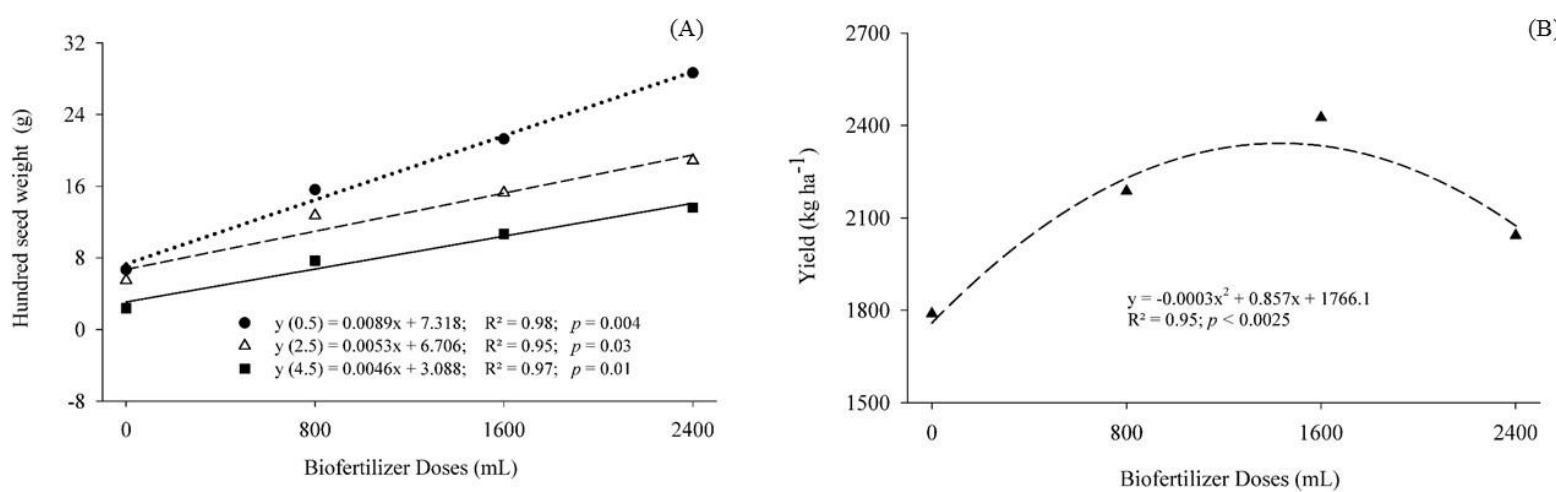

Fig 6. Hundred seed weight (A) and yield (B) of cowpea submitted to three levels of salinity (ECW: $0.5 ; 2.5$ and $4.5 \mathrm{dS} \mathrm{m}$ ) and four doses of mixed biofertilizer $(0,800,1600$ and $2400 \mathrm{ml}) . * *$ Significant at $1 \%$ probability.

of mixed biofertilizer, they had a maximum yield of 2378.14 $\mathrm{kg} \mathrm{ha}^{-1}$, while the minimum yield $\left(1789.15 \mathrm{~kg} \mathrm{ha}^{-1}\right)$ was seen when the plants did not receive the biofertilizer $(0 \mathrm{~mL})$ (Fig. $6 \mathrm{~B})$. When comparing the maximum with the minimum yield, there was a $24.77 \%$ increase in the cowpea yield for biofertilized plants (Fig. 6B).

Fertilization is one of the factors that most influence bean development and yield, since this crop is somehow exigent in terms of nutrient supply (Islam et al., 2016). Thus, the positive results for yield found in the present study are related to the supply of nutrients to the plants through the application of the mixed biofertilizer.

\section{Materials and Methods}

\section{Description of the experimental area}

The experiment was conducted in a greenhouse from July to September 2016 in an area of the experimental farm of the University for International Integration of Afro-Brazilian Lusophony - UNILAB, located in Piroás, municipality of Redenção, in Maciço of Baturité - CE, Brazil, at a latitude of 0414'53"S, longitude 3845'10" W, and average altitude varying from 240 to 340 . The local climate is classified as
Aw', that is, tropical rainy.

\section{Plant material}

Seeds of cowpea (Vigna unguiculata L.), Setentão cultivar, were used. Seeds were supplied by the Seed Analysis Laboratory of the Federal University of Ceará (UFC). They were planted in $16 \mathrm{~L}$ plastic containers containing soil from the area (eutrophic red-yellow argisol) and with a layer of gravel at the base to facilitate the drainage of irrigation water. Three seeds were sown per pot at a depth of $3 \mathrm{~cm}$ and manual thinning was done after one week, leaving only one plant in each pot. A total of 60 plants were used; they were identified according to the experimental design.

\section{Experimental design}

The experimental design was completely randomized in a $3 x$ 4 factorial scheme corresponding to three levels of salinity of irrigation water ( $\mathrm{ECW}$ : 0.5, 2.5 and $4.5 \mathrm{dS} \mathrm{m}^{-1}$ ) and four doses of mixed biofertilizer (formulated with a mixture of goat manure, poultry and wood ash) applied to the soil in liquid form, corresponding to $0,5,10$ and $15 \%$ of the soil volume, corresponding to the doses of $0,800,1600$ and $2400 \mathrm{~mL}$, 
respectively, with five replicates. The experiment lasted 100 days starting at the beginning of the application of treatments, and the plants were kept in a greenhouse with $50 \%$ shading.

\section{Cultivation treatments}

After planting, during the whole cycle of cowpea, crop practices necessary for proper cultivation were implemented, including thinning, staking, cleaning of old leaves, and elimination of weeds. The vertical staking method, where plants are vertically tied at tutors with the help of wood and wire stakes, was used in this case, for it promotes a better distribution of solar radiation, ventilation, and greater efficiency of phytosanitary control.

\section{Soil characterization}

In order to analyze the soil conditions used in the experiment, composite soil samples representative of the different treatments were collected before the soil was used. After being duly identified, the samples were sent to the Soil Chemistry and Fertility Laboratory of the Federal University of Ceará (UFC) for determination of the main chemical attributes. Results are shown in Table 2.

\section{Preparation of the biofertilizer and calculation of the doses}

The aerobic biofertilizer used was prepared in $500 \mathrm{~L}$ polyethylene boxes using a mixture of goat manure $(100 \mathrm{~L})$, wood ash $(10 \mathrm{~L})$, and water $(200 \mathrm{~L})$. Five applications of the mixed biofertilizer were made once a week, according to the doses calculated for treatments $0,5,10$ and $15 \%$ of the soil volume $(0,800,1600$ and 2400 milliliters - $\mathrm{mL}$, respectively), starting at the 7th day after germination (DAG) and with the objective of meeting the nutritional needs of the crop.

The biofertilizer was manually applied in a localized manner to avoid direct contact of the fertilizer with the leaves of the plants. A sample of each of the five applications of the liquid biofertilizer was sent to the UFC Soil and Water Laboratory for chemical analysis. The results of this analysis are shown in Table 3.

In order to meet the nutritional requirements of the plants during the cowpea cycle, the fertilization recommended by Ribeiro (2002), published by Embrapa Meio Norte (Table 4) was used. Considering the total area of the vessel, which was $0.113 \mathrm{~m}^{2}$, the recommendation was transformed into $\mathrm{g}$ plant ${ }^{-}$ ${ }^{1}$, obtaining for $\mathrm{P}$ and $\mathrm{K}$ a value of $0.4 \mathrm{~g} \mathrm{plant}^{-1}$. Doses of the biofertilizer were calculated based on these results.

\section{Irrigation with saline water}

Regarding irrigation, the water sources used were prepared in tanks with a capacity of $200 \mathrm{~L}$, using $\mathrm{NaCl}, \mathrm{CaCl}_{2} \cdot 2 \mathrm{H}_{2} \mathrm{O}$ and $\mathrm{MgCl}_{2} \cdot 6 \mathrm{H}_{2} \mathrm{O}$ in the proportion of 7: 2: 1 . The concentration of salts was calculated by the following equation [Cs $\left(\mathrm{mmolcl}^{-1}\right)$ $=\mathrm{EC} \times 10]$, where: $\mathrm{Cs}=$ concentration of salts; $\mathrm{EC}=$ preestablished electrical conductivity (Rhoades et al., 2000). Irrigation was performed every two days and the amount of water applied was estimated with the objective of reaching the soil field capacity, adding a leaching fraction of 0.15 for water percolation in the bottom of the pots, in order to avoid excessive accumulation of salts. The application of water was also manual, in a localized manner, to avoid direct contact with the leaves of the plants.

\section{Variables evaluated}

At 70 days after planting (DAP), the length of the main stem (LMS) and stem diameter (SD) of the plants of each block were measured using a measuring tape graduated in centimeters and a digital caliper graduated in millimeters, respectively. MSL was measured from the base at the level of the soil up to insertion of the last leaf, and SD was measured at the base of the stem.

At the end of the experiment, 70 DAP, the plants were collected and the shoots of each of them was fractionated into leaves and stems and placed in properly identified paper bags. Thereafter, leaf area (LA) was determined using a leaf area meter (LI-3100, Area Meter, Li-Cor., Inc., Lincoln, 87 Nebraska, USA). To determine the total dry mass (TDM), the plant organs were separated and placed in a greenhouse with forced air circulation at $65^{\circ} \mathrm{C}$ until reaching constant value (approximately for 72 hours). Then, the plant materials were weighed to determine the dry mass in grams per plant. After separation of the shoots of each plant, the pods were also collected, placed in properly identified paper bags and sent to the laboratory for quantification of number of pods per plant (NPP), average pod size (APS), total pod weight (TPW), total seed weight (TSW), and hundred seed weight (HSW). NPP was quantified by counting the pods produced by each plant, while APS was measured with a measuring tape graduated in centimeters. For the variables TPW, TSW and W100S, a precision scale was used to determine the dry mass in grams. One hectare $\left(10,000 \mathrm{~m}^{2}\right)$ and the pot area $\left(0.113 \mathrm{~m}^{2}\right)$ were used as reference for the calculation of yield $\left(\mathrm{kg} \mathrm{ha}^{-1}\right)$, obtaining a plant stand of 88,486 plants ha ${ }^{-1}$.

At $70 \mathrm{DAP}$, the net photosynthetic rate $(A)$, stomatal conductance $\left(\mathrm{g}_{\mathrm{s}}\right)$, and transpiration rate $(\mathrm{E})$ were measured on fully developed leaves of the middle third of the plants. Measurements were made between 9:00 and 12:00 p.m., using an infrared gas analyzer (IRGA) (portable model LI6400xt, LI-COR Biosciences Inc., Lincon, Nebraska, USA), under saturated radiation, controlled $\mathrm{CO}_{2}$ concentration (400 $\mathrm{ppm}$ ) and ambient temperature conditions.

\section{Statistical analysis}

Qualitative data of the analyzed variables were submitted to analysis of variance and when significance was found in the $F$ test, they were submitted to the Tukey test at $5 \%$ level of significance. In the case of quantitative data, a regression analysis was performed. The equations that best fitted the data were selected based on the significance of the regression coefficients to $1 \%$ and $5 \%$ of probability by the $F$ test and with the highest coefficient of determination $\left(R^{2}\right)$. The computational sofware "ASSISTAT 7.7 BETA" was used to carry out the statistical analysis, according to Silva et al. (2016).

\section{Conclusion}

The mixed biofertilizer promoted increases in the physiological and productive growth parameters when the plants were irrigated with saline water up to $2.5 \mathrm{dS} \mathrm{m}^{-1}$. The application of weekly doses of $1600 \mathrm{~mL}$ of mixed biofertilizer promotes greater leaf expansion of cowpea plants, increasing the physiological efficiency and production of the crop. The use of the biofertilizer can be indicated for cowpea because its application reduces the negative effects of saline 
water to the biometric, physiological and productive variables, aiding in the full development of the crop.

\section{Acknowledgements}

To the University of International Integration of AfroBrazilian Lusophony for the provision of space to perform the experiment, to the students and teachers involved, especially to José Wagner da Silva Melo, Ph.D. Adjunct Professor of the Phytotechnology Department of the Federal University of Ceará for sharing his knowledge, and to the National Council for Scientific and Technological Development - $\mathrm{CNPq}$, for the financing of the scientific initiation grant.

\section{References}

Acosta-Motos J, Ortuño M, Bernal-Vicente A, Diaz-Vivancos P, Sanchez-Blanco M, Hernandez, J (2017) Plant responses to salt stress: adaptive mechanisms. Agron J. 7: 1-38.

Ambede JG, Netondo GW, Mwai GN, Musyimi DM (2012) $\mathrm{NaCl}$ salinity affects germination, growth, physiology, and biochemistry of bambara groundnut. Braz J Plant Physiol. 24: 151-160.

Aquino JPA, Bezerra AAC, Alcântara Neto F, Lima CJGS, Sousa RR (2017) Morphophysiological responses of cowpea genotypes to irrigation water salinity. Rev Caatinga. 30: 1001-1008.

Bargaz A, Lyamlouli K, Chtouki M, Zeroual Y, Dhiba D (2018) Soil microbial resources for improving fertilizers efficiency in an integrated plant nutrient management system. Front Microbiol. 9: 1-25.

Bezerra AAC, Costa Filho RS, Oliveira SRM, Freire Filho FR (2018) Morphophysiological biometry and grain production in cowpea under different phosphorus levels. Comunicata Scien. 9: 275-281.

Chaves MM, Costa JM, Saibo NJM (2011) Recent advances in photosynthesis under drought and salinity. Adv Bot Res. 57: 49-104.

Dias FTC, Bertini CHCM, Freire Filho FR (2016) Genetic effects and potential parents in cowpea. Crop Breed Appl Biot. 16: 315-320.

Dinesh R, Srinivasan V, Hamza S, Manjusha A (2010) Shortterm incorporation of organic manures and biofertilizers influences biochemical and microbial characteristics of soils under an annual crop [Turmeric (Curcuma longa L.)]. Bioresource technol. 101: 4697-4702.

Formiga LDA, Guerra HOC, Lacerda RD, Silva EB, Araujo MS (2014) Efeito da água disponível do solo no comportamento de dois cultivares de mamona, nos primeiro e segundo ciclos. Eng Agric. 34: 1128-1138.

Gbaguidi AA, Dansi A, Loko LY, Dansi M, Sanni A (2013) Diversity and agronomic performances of the cowpea (Vigna unguiculata Walp.) landraces in Southern Benin. Int Res J Agr Sci and Soil Sci. 3: 121-133.

Giuliani MM, Carucci F, Nardella E, Francavilla M, Ricciardi L, Lotti C, Gatta G (2018) Combined effects of deficit irrigation and strobilurin application on gas exchange, yield and water use efficiency in tomato (Solanum lycopersicum L.). Sci Hortic-Amsterdam. 233: 149-158.

Islam MA, Boyce AN, Rahman MM, Azirun MS, Ashraf MA (2016) Effects of organic fertilizers on the growth and yield of bush bean, winged bean and yard long bean. Braz Arch Biol Techn. 59: 1-9.
Ju I, Wj B, Md S, la O, Oj E (2018) A review: Biofertilizer-A key player in enhancing soil fertility and crop productivity. J Microbiol Biotechn. 2: 22-28.

Lacerda CF, Sousa GG, Silva FL, Guimarães FV, Silva GL, Cavalcante LF (2011) Soil salinization and maize and cowpea yield in the crop rotation system using saline waters. Eng Agric. 31: 663-675.

Lima GS, Nobre RG, Gheyi HR, Soares LAA, Silva AO (2014) Cultivo da mamoneira sob estresse salino e adubação nitrogenada. Eng Agric. 34: 854-866.

Malusá E, Sas-Paszt L, Ciesielska J (2012) Technologies for beneficial microorganisms inocula used as biofertilizers. Scien World J. 2012:1-12.

Mishra P, Dash D (2014) Rejuvenation of biofertilizer for sustainable agriculture and economic development. Consilience. 11: 41-61.

Mohamed AK, Basalah MO (2015) The active role of calcium chloride on growth and photosynthetic pigments of cowpea "Vigna unguiculata L. (Walp)" under salinity stress conditions. Am Eurasian J Agr Env Sci. 15: 2011-2020.

Nardi S, Pizzeghello D, Schiavon M, Ertani A (2016) Plant biostimulants: physiological responses induced by protein hydrolyzed-based products and humic substances in plant metabolism. Sci Agric. 73: 18-23.

Neves ALR, Lacerda CF, Sousa CHC, Silva FLB, Gheyi HR, Ferreira FJ, Andrade Filho FL (2015) Growth and yield of cowpea/sunflower crop rotation under different irrigationm anagement strategies with saline water. Cienc Rural. 45: 814-820.

Nobre RG, Gheyi HR, Correia KG, Soares FAL, Andrade LO (2010) Crescimento e floração do girassol sob estresse salino e adubação nitrogenada. Rev Cienc Agron. 41: 358 365

Oliveira FDA, Medeiros JF, Oliveira MK, Souza AA, Ferreira JA, Souza MS (2013) Interação entre salinidade e bioestimulante na cultura do feijão caupi. Rev Bras Eng Agr Amb. 17: 465-471.

Pereira FAL, Medeiros JF, Gheyi HR, Dias NS, Preston W, Vasconcelos CB (2017) Tolerance of melon cultivars to irrigation water salinity. Rev Bras Eng Agr Amb. 21: 846851.

Petropoulos SA, Levizou E, Ntatsi G, Fernandes A, Petrotos K, Akoumianakis K, Barros L, Ferreira ICFR (2017) Salinity effect on nutritional value, chemical composition and bioactive compounds content of Cichorium spinosum $\mathrm{L}$. Food Chem. 214: 129-136.

Reis MM, Santos LD, Pegoraro RF, Colen F, Rocha LM, Ferreira GAP (2016) Nutrition of Tithonia diversifolia and attributes of the soil fertilized with biofertilizer in irrigated system. Rev Bras Eng Agr Amb. 20: 1008-1013.

Rhoades J, Kandiah A, Mashali AM (2000) Uso de águas salinas para produção agrícola. Campina Grande: UFPB. Estudos da FAO, Irrigação e Drenagem. 117p.

Ribeiro VQ (2002) Cultivo do feijão-caupi (Vigna unguiculato (L.) Walp). Sistema de Produção - Embrapa Meio-Norte. $108 \mathrm{p}$.

Shrivastava P, Kumar R (2015) Soil salinity: a serious environmental issue and plant growth promoting bacteria as one of the tools for its alleviation. Saudi J Biol Sci. 22: 123-131.

Silva FAS, Azevedo CAV (2016) The Assistat Software Version 7.7 and its use in the analysis of experimental data. Afr J Agr Res. 11: 3733-3740. 
Silva FLB, Lacerda CF, Neves ALR, Sousa GG, Sousa CHC, Ferreira FJ (2013) Irrigação com águas salinas e uso de biofertilizante bovino nas trocas gasosas e produtividade de feijão-de-corda. Irriga. 18: 304-317.

Silva FLB, Lacerda CF, Sousa GG, Neves AL, Silva GL, Sousa CH (2011) Interação entre salinidade e biofertilizante bovino na cultura do feijão-de-corda. Rev Bras Eng Agr Amb. 15: 383-390.

Silva VSG, Santos CERS, Freitas ADS, Stamford NP, Silva, AF (2016) Systems of land use affecting nodulation and growth of tree legumes in different soils of the Brazilian semiarid area. Afr J Agr Res. 11: 3966-3974.

Silva WC, Moura JG, Oliveira AB, Ferreira LE, Silva TM (2017) Growth and gas exchange in cowpea plants under different managements and saline conditions. Rev Cienc Agron, 48:
756-764.

Sousa GG, Rodrigues VS, Soares SC, Damasceno IN, Fiusa JN, Saraiva SE (2018) Irrigation with saline water in soybean (Glycine max (L.) Merr.) in a soil with bovine biofertilizer. Rev Bras Eng Agr Amb. 22:604-609.

Souza JTA, Cavalcante LF, Nunes JC, Bezerra FTC, Nunes JAS, Silva AR, Oresca D, Cavalcante AG (2016) Effect of saline water, bovine biofertilizer and potassium on yellow passion fruit growth after planting and on soil salinity. Afr J Agr Res. 11: 2994-3003.

Taiz L, Zeiger E, Moller IM, Murphy, A (2017) Physiology and plant development (6th ed.). Porto Alegre: Artmed 858 p.

Zandonadi DB, Santos MP, Busato JG, Peres LEP, Façanha AR (2013) Plant physiology as affected by humified organic matter. Theor Exp Plant Phys. 25: 13-25. 